\title{
$\bullet$ \\ The Role of Phytoconstituents in the Development of Newer Drug Compounds
}

\author{
IJCRR \\ Section: Healthcare \\ ISI Impact Factor \\ (2019-20): 1.628 \\ IC Value (2019): 90.81 \\ $\operatorname{SJIF}(2020)=7.893$

\section{Gakhar A ${ }^{1}$, Singla $\mathbf{N}^{2}$}

'Associate Professor, Department of Botany, KVA DAV College for Women, Karnal 132001 Haryana, India; ${ }^{2}$ Director, Accura Research Chemi-

cals, 11CT, Hyderabad 500049 Telangana, India.

\section{ABSTRACT}

Introduction: Natural products have been used in clinical therapeutics since time immemorial. It has been estimated that $56 \%$ of the lead compounds for medicines in the British National Formulary are natural products or are derived from natural products.

Materials: Despite the achievements of synthetic chemistry and the advances towards rational drugs design, 50 important natural products are described which continue to be essential in providing medicinal compounds and as starting points for the development of synthetic analogues.

Result: This article describes the phytoconstituents which are being used as lead compounds for the design, synthesis and development of Novel Drug Compounds.

Conclusion: Despite the achievements of synthetic chemistry and the advances towards rational drugs design, natural products will continue to be important in three areas of drug discovery: they can be used as a target for production by biotechnology, as a source of new lead compounds of the novel chemical structure and as active ingredients for useful treatments following the traditional system of medicines. Moreover, along with biologically active primary plant metabolites, secondary compounds also serve additionally as chemical models or templates for the design and total synthesis of new drug entities.

Key Words: Natural products, Lead compounds, Therapeutics, Medicinal compounds, Phytoconstituents

\section{INTRODUCTION}

Natural products have been a major source of drugs for centuries. ${ }^{1}$ With more than $25 \%$ of the pharmaceuticals in use today are derived from natural products. Pharmaceutical scientists are experiencing difficulty in identifying new lead structure, templates and scaffold in the finite world of chemical diversity. Although interest in natural products as a source of new biologically active compounds have decreased in the last few decades as synthetic chemistry programs have expanded ${ }^{1}$. But numbers of synthetic drugs have adverse and unacceptable side effects. Natural Products Still Continue to form a significant proportion of drugs in current use. It has been estimated that $56 \%$ of the lead compounds for medicines in the British National Formulary are natural products or are derived from natural products. ${ }^{2}$ Of the top 20 bestselling pharmaceutical products in 1990 , four were derived from natural products (amoxicillin, cefaclor, ceftriaxone, and lovastatin) and two others (captopril and enalapril) resulted from leads provided by a natural product. ${ }^{3}$ In 1991, 42 new agents were introduced to medical practice; of these, 16 were natural products or were derived from the natural product. Similarly, there were 43 new chemical entities introduced in 1992, and 18 were natural products or their derivatives. ${ }^{4}$ This article summarizes the natural products that have been used as lead compounds for the design, synthesis and development of Novel Drug Compounds.

\section{Natural products in drug discovery}

Plant products are useful as starting materials for the semisynthetic preparation of other drugs. The main examples are plant steroids for the manufacture of oral contraceptives and other steroidal hormones. Diosgenin from several species of yams (Dioscorea deltoidea) and echogenic from sisal leaves (Agave sisalana) are the main compounds used. ${ }^{5}$ There has been an impressive success with botanical medicine, most notably quing-has and artemisinin from Chinese medicine. ${ }^{6}$ Considerable research in pharmacognosy, chemistry, pharma-

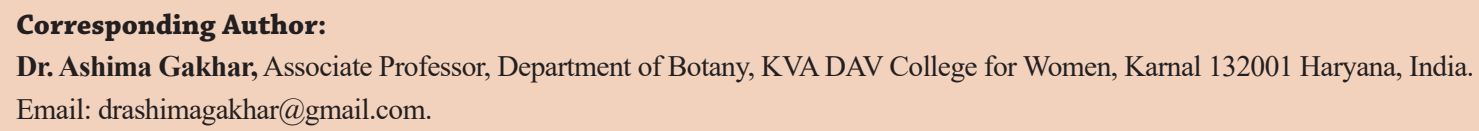


cology and clinical therapeutics has been carried out on ayurvedic medicinal plants. ${ }^{7}$ Natural compounds of pharmaceutical importance that were once obtained from higher plant sources, but which are now produced commercially largely by synthesis, include caffeine, theophylline, theobromine, ephedrine, pseudoephedrine, emetine, papaverine, L-dopa, salicylic acid and A-tetrahydrocananbinol. ${ }^{9}$ Biologically active plant-derived metabolites have found direct medicinal application as drug entities. Bioactive plant compounds have proven useful as 'leads' or model compounds for drug synthesis or semisynthesis For eg. Beta-carotene, a plant primary metabolite that is useful in the prevention and/or treatment of certain cancers is currently produced synthetically on a commercial scale ${ }^{8}$. Despite that numerous examples of economically synthesizable natural product (Table no. 1), it is frequently forgotten that plant secondary compound can, and often do serve additionally as chemical models or templates for the design and total synthesis of new drug entities. ${ }^{24,25}$ For example, atropine for tropicamide, quinine for chloroquine, cocaine for procaine and tetracaine, opium alkaloids for codeine and morphine have served as models for the design and synthesis of anticholinergic, antimalarial drugs. ${ }^{2,}{ }^{8}$ Similarly, the study of the synthetic analogue of khellin, a Furano chrome derived from the fruits of Ammi visnaga $(\mathrm{L}$.) Lam. is formally marketed in the United States as a bronchodilator and a coronary medication that led to the preparation and development of disodium cromolyn, also known as cromolyn sodium. Cromolyn is now a major drug used as a bronchodilator and for its antiallergenic property. Related synthetic studies based on the benzofur and moiety eventually led to the development of amiodarone, which was originally introduced in Europe as a coronary vasodilator of angina, but which was subsequently found to have a more useful application in the treatment of the specific type of arrhythmias, the wolf-Parkinson syndrome, and for arrhythmias resistant to other drugs. ${ }^{9}$

In still another example, the guanidine type alkaloids, galegins, the active principle of goat's rue (Galega officinalis L.), were used clinically for the treatment of diabetics. It had been known for some times previous to this discovery that guanidine itself had anti-diabetic properties, but was too toxic for human use. After hundreds of synthetic compounds were prepared, metformin, a close relative to galegin was developed and marketed as a useful antidiabetic drug. ${ }^{10}$ Despite the achievements of synthetic chemistry and the advances towards rational drugs design, natural products continue to be essential in providing medicinal compounds and as starting points for the development of synthetic analogues. Plant-derived drug thus represent stable markets upon which both physicians and patients rely. In addition, worldwide markets in plant-derived drugs are difficult to estimate, but undoubtedly amount to many additional billions of dollars. ${ }^{11,12,13}$
Plants continue to be an Important Source of Drugs, as the recent approval in the United States, of several new plantderived drugs, and semi-synthetic and synthetic drugs based on plant secondary compounds. For example taxol (paclitaxel), an anticancer taxane diterpenoid derived from the relatively scarce Pacific or western yew tree, Taxus brevifolia Nutt., was approved in the United States for the treatment of refractory ovarian cancer ${ }^{12}$. Etoposide is a relatively new semisynthetic antineoplastic agent based on podophyllotoxin, a constituent of the mayapple (also known as American mandrake), Podophyllum peltatum. ${ }^{17,18,19}$ which is useful in the chemotherapeutic treatment of refractory testicular carcinoma, small cell lung carcinoma, non-lymphatic leukaemia, and non-Hodgkin's lymphoma. ${ }^{13}$ Atracurium besylate is a relatively new synthetic relaxant, which is structurally and pharmacologically related to the curare alkaloids. In addition, synthetic $\mathrm{A}^{9}$-tetrahydrocannabinol (originally derived from the marijuana plant, Cannabis sativa L.) and some of its synthetic analogues (e.g., nabilone) has recently been approved in The U.S. for treatment of nausea associated with cancer chemotherapy. ${ }^{15,16}$

Cannabinoids are also being developed for the use in glaucoma and in neurological disorders (e.g. epilepsy and dystonia), and as antihypertensives (cardiovascular agents), antiasthmatics (bronchodilator), and potent analgesics. ${ }^{3,20-24}$

Plant-derived drugs which are currently undergoing development and testing include the Chinese drug artemisinin (qinghaosu) and several of its derivatives, which are newly, discovered rapidly acting antimalarial agents derived from Artemisia annua and forskolin, a naturally occurring labdane diterpene with antihypertensive, positive inotropic, and adenylyl cyclase-activating properties. Forskolin is derived from the root of Coleus forskohlii plant used in East Indian folk medicine and cited in ancient Hindu and Ayruvedictexts $^{6,10}$. In addition to the compounds mentioned above, several other bioactive plant secondary metabolites are being investigated for their potential utility. ${ }^{25,26}$ For example, the medicinally active organosulphur compounds of garlic and onion are being investigated and evaluated as potentially useful cardiovascular agents and ellagic acid, Beta-carotene, and vitamin (tocopherol) are being tested and evaluated for there possible utility as prototype anti-mutagenic and cancer prevention agents. ${ }^{12,14}$

\section{CONCLUSION}

Experimental agents from natural products are offering us a great the opportunity to evaluate new chemical classes of medicinal agents, as well as novel and potentially relevant mechanisms of action. Despite the achievements of synthetic chemistry and the advances towards rational drugs design, natural products will continue to be important in three areas 
of drug discovery: they can be used as a target for production by biotechnology, as a source of new lead compounds of the novel chemical structure and as active ingredients for useful treatments following the traditional system of medicines. Moreover, along with biologically active primary plant metabolites, secondary compounds also serve additionally as chemical models or templates for the design and total synthesis of new drug entities.

\section{Conflict of Interest : None}

\section{Source of Funding: None}

\section{REFERENCES}

1. Farnsworth NR, Akerele O, Bingel AS, Soejarto DD, Guo Z. Medicinal plants in therapy. Bull World Health Organ. 1985, 63:965-981.

2. Sumantran VN. Experimental approaches for studying uptake and action of herbal medicines. Phytoth Res. 2007; 21: 210.

3. Hobden AN and Harris TJ, The impact of biotechnology and molecular biology on the pharmaceutical industry. Soc Edinburgh Sect B. 1992; 99:37.

4. Davis J, New chemical entities disappoint in 1992, Scrip review 1992.PJB publications. 1993; 21:20-21.

5. Rollinger JM. Strategiesforefficientleadstructurediscovery from natural products, Curr Med Chem. 2006;13: 1491.

6. Jan P, Coelmont L, Vliegen I, Hemel JV.Heminpotentiates the anti-hepatitis $\mathrm{C}$ virus activity of the antimalarial drug artemisinin, Biochem Biophy Res Comm. 2006;348:139-144.

7. John AP, Healing plant of peninsular India, CABI Publishing, 2001, 217.

8. Foye WO, Principles of Medicinal Chemistry, Lea and Febiger: Philadelphia, PA, 3rdEd, 1989,64.

9. Dahanukar SA, Kulkarni RA and Rege NN. Pharmacology of medicinal plants and natural products. Ind J Pharmac. 2000;37: 231.

10. Sneader W, Drug Discovery: The Evolution of Modern Medicines, John Wiley and Sons: Chichester. 1985;12:165.

11. Mukherjee P. Quality control of herbal drugs, Horizons publishers, Istedition, 2002, 35.
12. Tabata H. Paclitaxel production by plant cell culture technology, Adv Biochem Engg Biotech. 2004; 87,1-23.

13. Ariga $\mathrm{T}$ and Seki $\mathrm{T}$, Antithrombotic and anticancer effects of garlic derived sulphur compounds. Biofactors. 2006, 26,93-103.

14. Griebenow R, Pittrow DB, Weidinger G and Mutschler E, Antihypertensive efficacy and tolerability of low-dose reserpine/thiazide combination compared anace-inhibitor in first-line treatment. Am J Hypert. 1996; 9: 119.

15. Kunio S, Isolation and characterization of angiotensin I-converting enzyme inhibitor dipeptides derived from Allium sativum L (garlic). J Nutrit Biochem. 2017;9: 415-419.

16. Lindsay B, Erland E and Richard T, Digitalis structure-activity relationship analysis: Conclusions from indirect binding studies with cardiac $(\mathrm{Na}++\mathrm{K}+)$-ATPase. Biochem Pharmac.1983; 32: 2767-2774.

17. Sumitra M, Manikandan P, Kumar DA, Balakrishnan K, Manohar BM and Puvana Krishnan R, Experimental myocardial Necrosis in Rats - Role of ArjunolicAcid on Platelet aggregation, coagulation and Antioxidant status. J Molec Cell Biochem. 2001; 224:135-142.

18. Giuffre G, Caputo $G$ and Peluso F, Platelet rich plasma treatment and heomatasis in patients with hemorrhagic risk. Minerva Stomatol. 2006; 55:599-609.

19. Duxbury BM and Poller L, The oral anticoagulant saga: past, present, and future, Clin Appl ThrombHemost. 2001; 7,269-75.

20. Power I, and McCormack J, Postoperative pain management: new, convenient analgesic therapies. Expert Opin Pharmacother. 2007; 8:391-9.

21. Simasek M and Blandino DA, Treatment of the common cold. Am Fam Physician, 2007; 75: 515-20.

22. Jasjeet $\mathrm{K}$ and Gurvinder SS, Diuretic activity of organomercury(II) complexes of theophylline and theobromine. J Inorg Biochem. 1992; 48:305-310.

23. Misso S, The Theobromine class of diuretics. The Lancet. 1907; 169:602-603.

24. Lachkar Y and Bouassida W, Drug induced acute angle glaucoma, Curr Opin Ophthalmol. 2007; 18:129-33.

25. Ishida N, Odani-Kawabata N, Shimazaki A and Hara H, Prostanoids in treatment of glaucoma. Cardiovasc Drug Rev. 2006; 24:1-10

26. Noedl H, Krud Sood S, Laowattana W. In Vitro Antimalarial Activity Of Azithromycin,artesunate, and quinine in combination and correlation with clinical outcome. Antimicrob Agents Chemother. 2007; 51: 651-6. 
Table 1: Therapeutic pure phyto-constituents as useful drugs are enlisted

\begin{tabular}{|c|c|c|c|c|c|c|}
\hline $\begin{array}{l}\text { Plant } \\
\text { source }\end{array}$ & Part used & $\begin{array}{l}\text { Active } \\
\text { phytoconstituents }\end{array}$ & Family & Structure & Therapeutic use & References \\
\hline $\begin{array}{l}\text { Rauwolfia } \\
\text { serpentine }\end{array}$ & $\begin{array}{l}\text { Roots and } \\
\text { rhizomes }\end{array}$ & Reserpine & Apocyanaceae & & Antihypertensive & 14 \\
\hline $\begin{array}{l}\text { Allium } \\
\text { sativum }\end{array}$ & Bulbs & Allin & Liliaceae & & Antihypertensive & 15 \\
\hline $\begin{array}{l}\text { Digitalis } \\
\text { purpurea }\end{array}$ & Leaves & Digitoxigenin & Scrophularaceae & & Cardiotonic & 16 \\
\hline $\begin{array}{l}\text { Terminalia } \\
\text { arjuna }\end{array}$ & Stem bark & Arjunolic acid & Combretaceae & & Antiplatelet effect & 17 \\
\hline $\begin{array}{l}\text { Melilotus } \\
\text { officinalis }\end{array}$ & leaves & Dicoumarol & Leguminosoea & & Anticoagulant & 18,19 \\
\hline $\begin{array}{l}\text { Cinchona } \\
\text { officinalis }\end{array}$ & Stem bark & Quinidine & Rubiaceae & & Antiarrythmic & 20 \\
\hline $\begin{array}{l}\text { Papaver } \\
\text { somniferum }\end{array}$ & Latex & Codeine & Papaveraceae & & $\begin{array}{l}\text { Analgesic and } \\
\text { sedative }\end{array}$ & 21,22 \\
\hline $\begin{array}{l}\text { Theobrom } \\
\text { a cocoa }\end{array}$ & $\begin{array}{l}\text { Dried ripe } \\
\text { seeds }\end{array}$ & Theobromine & Sterculiaceae & & $\begin{array}{lr}\text { Diuretic } & \text { and } \\
\text { smooth } & \text { mus } \\
\text { relaxant } & \text { cle }\end{array}$ & 23,24 \\
\hline $\begin{array}{l}\text { Pilocarpus } \\
\text { jaborandi }\end{array}$ & Leaflets & Pilocarpine & Rutaceae & & Glaucoma & 25,26 \\
\hline Vicia fabe & Seeds & L-dopa & Leguminoseae & & Antiparkinsonisum & 27 \\
\hline $\begin{array}{l}\text { Condrode } \\
\text { ndron }\end{array}$ & Stem bark & Tubocurarine & Menispermaceae & & $\begin{array}{l}\text { Skeltal } \\
\text { muscle relaxant }\end{array}$ & 28 \\
\hline
\end{tabular}


Table 1: (Continued)

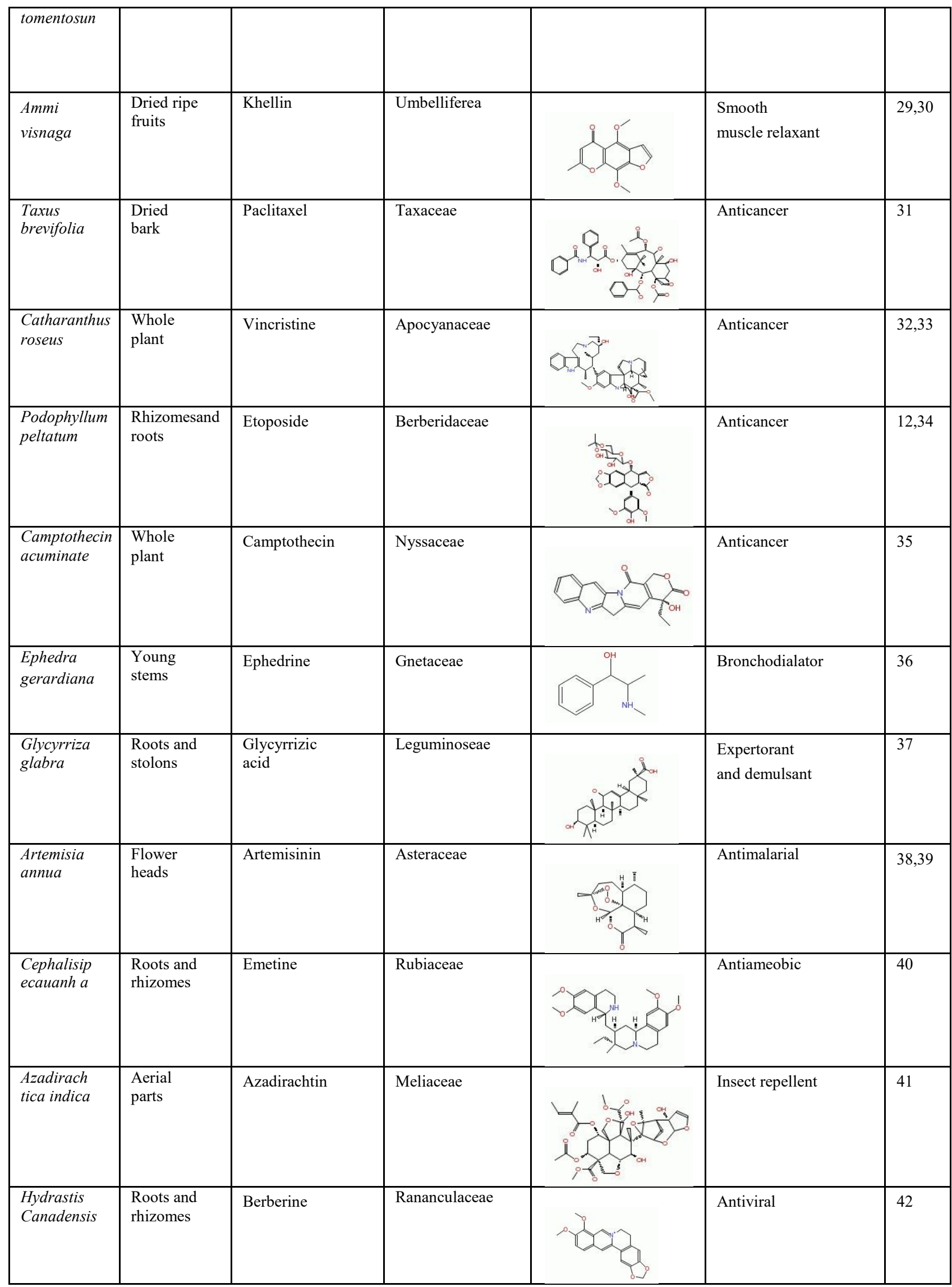


Table 1: (Continued)

\begin{tabular}{|c|c|c|c|c|c|}
\hline $\begin{array}{l}\text { Piper } \\
\text { longum }\end{array}$ & $\begin{array}{l}\text { Unripe } \\
\text { fruits }\end{array}$ & Piperine & Piperaceae & Antifertility & 43 \\
\hline $\begin{array}{l}\text { Plumbago } \\
\text { zeylanica }\end{array}$ & Roots & Plumbagin & Plumbaginaceae & Antifertility & 44 \\
\hline $\begin{array}{l}\text { Bligias } \\
\text { apinda }\end{array}$ & $\begin{array}{l}\text { Unripe } \\
\text { fruits }\end{array}$ & Hypoglycin A & Sapincdaceae & Antidiabetic & 45 \\
\hline $\begin{array}{l}\text { Androgra } \\
\text { phis } \\
\text { paniculata }\end{array}$ & $\begin{array}{l}\text { Dried leaves } \\
\text { andshoots }\end{array}$ & Andrographolide & Acanthaceae & Antidiabetic & 46 \\
\hline $\begin{array}{l}\text { Silibiumma } \\
\text { rium }\end{array}$ & Seeds & Silibin & Asteraceae & Hepatoprotective & 47,48 \\
\hline $\begin{array}{l}\text { Solanum } \\
\text { pseudocar } \\
\text { pum }\end{array}$ & $\begin{array}{l}\text { Dried leaves } \\
\text { andberries }\end{array}$ & Solasodine & Solanaceae & Hepatoprotective & 49 \\
\hline $\begin{array}{l}\text { Glycine } \\
\max \end{array}$ & $\begin{array}{l}\text { Dried } \\
\text { leaves }\end{array}$ & Apigenin & Leguminoseae & Hepatoprotective & 50 \\
\hline $\begin{array}{l}\text { Erythroxyl } \\
\text { um coca }\end{array}$ & $\begin{array}{l}\text { Dried } \\
\text { leaves }\end{array}$ & Cocaine & $\begin{array}{l}\text { Erythroxylace } \\
\text { ae }\end{array}$ & Neuroblocker & 51 \\
\hline $\begin{array}{l}\text { Physostig } \\
\text { ma.venen }\end{array}$ & $\begin{array}{l}\text { Dried ripe } \\
\text { seeds }\end{array}$ & Physostigmine & leguminoseae & $\begin{array}{l}\text { Acetylcholinesterase } \\
\text { inhibitors }\end{array}$ & 52 \\
\hline
\end{tabular}

